\title{
Psychological Factors Influence EFL Students' Interest
}

\author{
Yolanda Resta Clasa Kanter \\ Program Studi Pendidikan Bahasa Inggris, Fakultas Keguruan dan Ilmu Pendidikan \\ Universitas Widya Gama Mahakam, Indonesia \\ Jl. KH. Wahid Hasyim No. 28 RT.007 Kota Samarinda, Provinsi Kalimantan Timur \\ clarakanter19@gmail.com
}

\begin{abstract}
:
The subject of this research was the students of SMP Negeri 34 Samarinda, and the object was this research was the factors that influence students' interest in learning English. The population and sample of this research were all of the students in class VIII at SMP N 34 Samarinda. They consisted of eight D classes. The total were number of the population was 27 students. The technique used in collecting data was questionnaire. To analyze the data, the researcher used descriptive statistic to analyze the data. The researcher used mean to known the score. Based on the data analysis, it can be seen that the factor that influence of students' interest is categorized into middle (63\%). There are some factors that influence students' interest in learning English. They are: internal factors (come from the students themselves such as attention, intelligence, and readiness) and external factors such us parent and teacher. The dominant factors that influence students interest is external factors from the teacher factor
\end{abstract}

Keywords: Students' Interest, Psychological Factors, EFL.

\section{Introduction}

English is one of the international languages that are most used in communicating with human beings. According to [6], he stated that English is one language that must be learned by all students from elementary school to university. English is also the first foreign language that is taught in school, including in Indonesia. However, in Indonesian that many students come from different place and backgrounds with unique academic needs, interests, language, culture, and attitudes toward learning English. English plays an important role as a global language, for example in the field of education. Based on [2] English language is important to learn because almost all of the global information in various aspects of life written or spoken in English. There are four language skills that the students who learn English as a foreign language should be provided.

According to [5] state four language skills that namely: listening, reading, speaking and writing. Beside skills the students also learn English languages with component as grammar especially tenses, pronunciation, vocabulary and so on. According to [3] learning a foreign language as an English language is not easy for student. So that is not an easy work for teacher to teach the students. Interest in learning English become a key factor to successful conversational ability among the students and which much influence them in learning English. Based on [8] state "interest" is an impression or feeling that cause special concern or attention to an object.

In other words, interest is the emotional condition of the students, it must not be ignored. Emotion, in all conditions, psychologically has such a profound effect on the success or failure of a language study. The researcher found many problems such as many students have a little or even less interest in learning English, they are not giving notice on the lessons, and there are some other students lazy and bored to learn English. The psychological problems of the student's interest. There is several factors psychology that influences students' interest in learning English. Such as, attention, readiness, intelligence. According to [4] interests are sources of motivation which drive people to do what they want to do when they are free to choose. Attention is an act or process of focusing on one or more information in learning process. Readiness is prepared to respond or act. It means that the student should have prepared in learning process. Intelligence is a skill to understand or learn or trying or deal with new 
situation. To make students interested in learning English teachers must have strategies and materials so learning English will be better. Although, learning English is the most difficult for students but students must learn about it. The purpose of this research to find the Psychological Factors Influence EFL students' interest. The problems related to students' lives in school. So, that they are able to solve their problems through the lessons they receive so that each member gets a better understanding.

\section{Methodology}

This research was survey research from quantitative approach, and it used cross-sectional survey design to conduct this research. Cross-sectional survey design is the data that collected by the researcher at one point in time [1]. Furthermore, this research has been conducted in in Eight Grade (VIII) at SMP N 34 Samarinda. The researcher decided that Eight Grade (VIII)as the population and VIII D as the sample which chosen by simple random sampling. According to [1] the most popular and rigorous form of probability sampling from a population is simple random sampling. Moreover, this research used questionnaire as the instrument, and it used Likert scale using 10 close-ended items on questionnaire. The questionnaire was adopted from [7]. In collecting the data the researcher asked permission of the Headmaster of SMP Negeri 34 Samarinda. Second, the researcher would distribute the questionnaires to the students two days later. Third, after the researcher analyzed the questionnaire to collect more information about the study.Finally, the researcher coded the data to ease in recognizing the differences and similarities among the data. The researcher gave the questionnaire to the respondent related to student's interest in learning English.

\section{Findings and Discussion \\ Finding}

In this point, the researcher described the findings of student interest in learning English. In addition, it was about psychological factors. The question can be seen from the questionnaires' items number $1-10$. The data are personated on the tables one by one are follows:

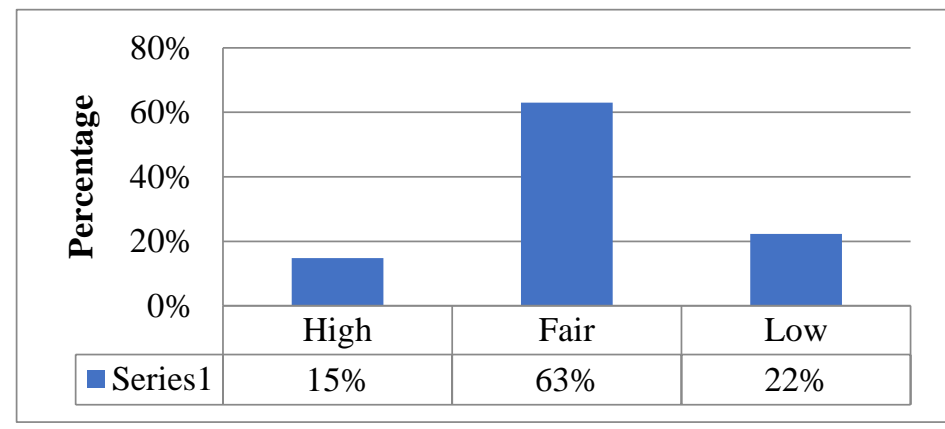

Figure 1. Psychological Factors Influence EFL Students’ Interest

The criteria of students' interest are high (78-100), fair (64-77), and low (0-63). From 27 respondents the researcher found that respondent get high score of psychological factor and the majority of them had fair for psychological factors influence EFL students' interest were 17 students.

\section{Discussion}

Based on the recapitulation table it can be conclude the factors that influence students' interest in learning English at the first year of students' SMP Negeri 34 Samarinda are describe bellow: 
From the statement of I was Concentration during Classroom Interaction, it was found there are 8 students who answered strongly agree, 14 students who answered agree, and 5 students who answered undecided. The conclusion is the majority of the students always concentration during classroom interaction. From the statement of I pay attention in teaching and learning English, there were 8 students who answered strongly agree, 13 students who answered agree, and 6 students who answered undecided. The majority of conclusion is that the students pay attention in teaching and learning English. From the statement of I prepared the next lesson before class, seen that 8 students who answered strongly agree, 11 students who answered agree, 7 students who answered undecided, and 1 who answered disagree. The conclusion is that the majority of the students always prepared the next lesson before class. From the statement of I was scared answer the question from teacher, seen that 2 students who answered strongly agree, 12 students who answered Agree, 11 students who answered undecided, and 2 who answered disagree. The conclusion is that the majority of the students are sometimes scared answering the questions from the teacher. From the statement of I feel anxiety in using the English in the classroom, there were 2 respondents chose strongly agree, 4 students who answered agree, 15 students who answered undecided, 4 who answered disagree, and 2 students who answered strongly disagree. The conclusion is that the majority of the students sometimes feel anxiety in using English in the classroom. From the statement of I was difficult to understand the text from English teacher, there were 2 students who answered stronly agree, 8 students who answered agree, 10 students who answered undecided, 4 who answered disagree, and 3 students who answered strongly disagree.The conclusion is the majority of the students undecided get difficult to understand the text from English teacher. From the statement of My family help me if I have about the problems in learning English, From the table above, there were 7 students who answered strongly agree, 11 students who answered agree, 4 students who answered undecided, 2 students who answered disagrree, and 3 who answered strongly disagree. The conclusion is that the majority of the students sometimes do not understand about the lesson.From the statement of My Family give full support for me in learning English, seen that 13 students who answered trongly agree, 9 students who answered agree, and 5 student who answered undecided. The conclusion is that the majority ofthe student's family always give full support for their children in learning English.From the statement of In English class My English teacher talked with us in simple English, there were 7 students who answered strongly agree, 14 students who answered agree, and 6 students who answered undecided. The conclusion is that the majority in English class their English teacher always talked with us simple English. From the statement of My English teacher makes me happy and relaxed, seen that 10 students who answered strongly agree, 15 students who answered agree, and 2 students who answered undecided. The conclusion is the majority of the students' teacher always makes their happy and relaxed.

\section{Conclusion}

In conclusion, the study shows that factors that influence of students' interest in learning English at SMP Negeri 34 Samarinda is the factor of school, it gets 63\%Middle. The dominant factors that influence students interest is external factors from the teacher factor.

\section{References}

[1] J.W. Creswell, "Educational Research: Planning, Conducting and Evaluating Quantitative and Qualitative Research", Boston: Pearson Education, Inc, 2012.

[2] P.M. Diana, "Why Is Learning English So Beneficial Nowadays?", International Journal of Communication Research, 2012.

[3] A. Hosain, "Difficulties of Learning English Language at the Secondary Level: A Case Study of Thakurgaon District", IBAIS University, Bangladesh, 2018. 
[4] B.E. Hurlock, "Child Development", Tokyo: McGraw-Hill, 2010.

[5] H. Noushad, "Language and Language Skills", Associate Professor in Education Maulana Azad National Urdu Univesity, 2015.

[6] D. Payne, "The Importance Of Learning English and Why it Should be Fun", 2014.

[7] S. Rahmah, "Factors Influencing Students' Interest In Learning English at The First Year Students Of SMU N 3", 2011.

[8] B. Vainikka, "Psychological Factors Influencing Consumer Behavior", New York: Pearson Education, 2015. 